\section{Cellular effects of lanthanides on Mytilus edulis}

\author{
P. Pharand, ${ }^{1,2}$ C. Brousseau-Fournier, ${ }^{1,2}$ \\ C. Côté, ${ }^{1,2}$ F. Gagné, ${ }^{3}$ M. Fournier, ${ }^{1,2}$ \\ P. Brousseau ${ }^{1,2}$ \\ ${ }^{1}$ Parc de la rivière Mitis, Ste-Flavie, \\ Québec; ' ${ }^{2}$ ISMER, Université du Québec \\ à Rimouski, Rimouski, Québec; \\ ${ }^{3}$ Environnement Canada, Centre Saint- \\ Laurent, Montréal, Québec, Canada
}

\section{Introduction}

Lanthanides form a small group of elements included between lanthanum (57) (La) and lutetium (71) (Lu) in the periodic table and they all present similar chemical and electrical properties. ${ }^{1}$ Lanthanides most common valence is $(+3)$ when dissolved, but present also $(+2)$ and $(+4)$ in oxidation states. ${ }^{1,2}$ Lanthanides ions, like $\mathrm{La}^{+3}$ and Gadolinium ${ }^{+3}$, show competition by blocking voltage-gated calcium channels in different type of cells and tissues since their ionic radii are similar to calcium ions $(+2,+3)$. Yttrium $^{+3}$, Erbium $^{+3}$, Neodynium $^{+3}$ and Cerium ${ }^{+3}$ also demonstrate the capacity of interfering with calcium channels. ${ }^{2,3}$ The elements $(+3)$ in this group are also able, among other things, to block $\mathrm{Na}^{+} / \mathrm{Ca}^{+2}$ synaptic plasma exchange membrane and the $\mathrm{Ca}^{+2}$-ATPase in the sarcoplasmic reticulum in musles. ${ }^{2}$ Lanthanides are also called rareearth elements but in fact, they are not that rare in nature. ${ }^{3}$ Indeed, they are used in many fields because of different properties such as metallurgical, optical and electronic industries which increase their artificial occurrence in nature and so the chances of those elements to get in contact with humans and animals, affecting their metabolic pressesses. ${ }^{3}$ Some lanthanides were also found in runoff and wastewater from agriculture sources, contaminating aquatic systems. ${ }^{1}$ The availability of lanthanides in water and sediments depends on various factors such as $\mathrm{pH}$, concentration, temperature and types of organic and inorganic ligants. ${ }^{1}$ The biological toxicity also varies according to the affected specie. ${ }^{1}$ The purpose of the present study is to determine the cytotoxic effect of some lanthanides on the blue mussel Mytilus edulis, a well-known sentinel species.

\section{Materials and Methods}

\section{Hemolymph collection and cellularity}

We know from some literature that lanthanides are not very cytotoxic. However, the viability was assessed in our experimental set- ting because it is a key element. Before doing any functional assay the viability must be determined. Measures were then taken on eight Mytilus edulis per lanthanide. Individuals were picked up at Mitis Bay $\left(48^{\circ} 40^{\prime} \mathrm{N}, 68^{\circ} 00^{\prime} \mathrm{W}\right)$ and punctured blank with sterile $3 \mathrm{~mL}$ syringes and 2 IG1 $1 \frac{1}{2}$ needles. Cellularity and viability were measured by flow cytometry with BD Accuri ${ }^{\mathrm{TM}} \mathrm{C} 6$ (Becton Dickinson, San Jose, CA, USA) and the software used was BD Accuri ${ }^{\mathrm{TM}}$ C6 Software (Becton Dickinson; version 1.0.264.21). Hemocyte populations were gated using a density plot (SSC vs FSC) and the fluorescence was recorded on FL3. Measurements were done using $200 \mathrm{~L}$ of cells exposed to propidium iodide at $10 \mu \mathrm{L}^{*} \mathrm{~mL}^{-1}$ (Sigma-Aldrich Inc., St. Louis, M0, USA) and those samples with more than $70 \%$ of viable cells were processed further.

\section{Lanthanides exposition}

The exposure with lanthanides was performed in vitro with $180 \mathrm{~L}$ of cells from organisms with high viability and the cells were exposed for $21 \mathrm{~h} 20 \mu \mathrm{L}$ of one of the seven lanthanides studied in a dose response manner. Lanthanum (La 138), Cerium (Ce 140), Neodymium (Nd 144), Samarium (Sm 154), Gadolinium (Gd 157), Erbium (Er 167) and Yttrium (Y 88) were used at final concentrations of $0 \mathrm{M}, 10^{-3} \mathrm{M}, 10^{-5} \mathrm{M}, 10^{-7} \mathrm{M}$ and $10^{-9} \mathrm{M}$ diluted in distilled water and samples. The cell viability was then reevaluated after the exposure with the same flow cytometry method.

\section{Statistical analysis}

The effect of the lanthanides cytotoxicity was expressed in mean \pm standard deviation
Correspondence: Michel Fournier, ISMER, Université du Québec à Rimouski, 310 Allée des Ursulines, Rimouski, QC G5L 3A1, Canada.

E-mail: michel_fournier@uqar.ca

Key words: Lanthanides; cell viability; flow cytometry; Mytilus edulis; blue mussel.

Conference presentation: part of this paper was presented at ECOBIM meeting, 2015 May, Québec City, Québec, Canada.

This work is licensed under a Creative Commons Attribution NonCommercial 3.0 License (CC BYNC 3.0).

(C) Copyright P. Pharand et al., 2015

Licensee PAGEPress, Italy

Journal of Xenobiotics 2015; 5:5781

doi:10.4081/xeno.2015.5781

and the signification of the results was determined by one-way analysis of variance (ANOVA). The sequences that failed normality test were analyzed by Kruskal-Wallis non-parametrical test. The statistics were calculated using SigmaPlot ${ }^{\circledR}$ version 12.5 software (Systat Software, Inc., San Jose, CA, USA).

\section{Results}

The results are presented in Figure 1 and expressed in percent of viable cells. The differences in viability between the controls and the most elevated concentrations $\left(10^{-3} \mathrm{M}\right)$ of lanthanides are mostly insignificant except for

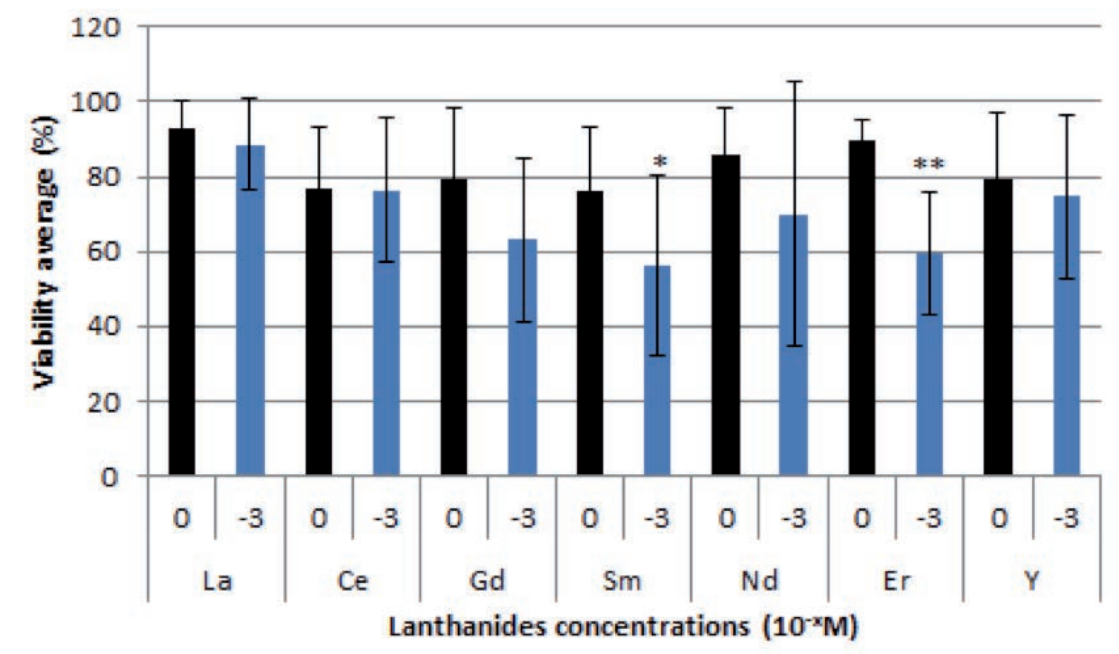

Figure 1. Average Mytilus edulis cell viability (\%) after $21 \mathrm{~h}$ of exposure to lanthanides ranging from 0 to $10^{-3} \mathrm{~mol}^{*} \mathrm{~L}^{-1}(\mathrm{M})$, significant results are presented with an asterisk. Figure shows averages but some statistical tests were produced with median when the distribution failed normality test. 
samarium and erbium where it decreases significantly All the lower concentrations do not present significant differences with the control or $10^{-3} \mathrm{M}$ of each lanthanide.

\section{Discussion and Conclusions}

The majority of the lanthanides used showed no effect that is consistent with other studies where lanthanides alone do not induce toxic effects. ${ }^{4}$ The concentrations used in this experiment are not far from the ones found in some industrial wastewater like in India where the higher concentration of samarium was around $10^{-5} \mathrm{M} .{ }^{5}$ However, the amounts generally found are below $10^{-7} \mathrm{M}^{5-7}$ Samarium, which is one of the few lanthanides that showed toxicity in the study even though it was at higher concentration then what is found in the environment, has many uses. It is mainly uses in drugs, laser, glass, electronic, nuclear and ceramic industries. ${ }^{5}$ Cytotoxicity as used in the present study may be not by itself an optimal marker to assess the potential effects of lanthanides because of other low cytotoxicity. Others parameters such as phagocytosis for instance for the immune system have to be measured in order to better understand the full impact of those elements on aquatic life. The monitoring of those elements also needs to go on, since the environmental concentrations are already high, and the climate changes may increase the release of lanthanides from the sediments and render them more available to aquatic ecosystem.

\section{References}

1. Gonzalez V, Vignati DAL, Leyval C, Giamberini L. Environmental fate and ecotoxicity of lanthanides: Are they a uniform group beyond chemistry?. Environ Int 2014;71:148-57.

2. Fricker SP. The therapeutic application of lanthanides. Chem Soc Rev 2006;35:52433.

3. Paasz A, Czekaj P. Toxicological and cytophysiological aspects of lanthanides action. Acta Biochim Pol 2000;47:1107-14.

4. Oliveira MS, Duarte IM, Paiva AV, Yunes SN, Almeida CE, Mattos RC, Sarcinelli PN. The role of chemical interactions between thorium, cerium, and lanthanum in lymphocyte toxicity. Arch Environ Occup $\mathrm{H}$ 2014;69:40-5.

5. Ratre P, Kumar D. Spectrophotometric determination of trace amounts of samarium in environmental samples. Am Int $\mathrm{J}$ Res Formal Appl Nat Sci 2013;3:110-8.

6. Bentlin FRS, Pozebon D. Direct determination of lanthanides in environmental samples using ultrasonic nebulization and ICP OES. J Braz Chem Soc 2010;21:627-34.

7. Kulaksiz S, Bau M. Rare earth elements in the Rhine River, Germany: first case of anthropogenic lanthanum as a dissolved microcontaminant in the hydrosphere. Environ Int 2011;37:973-9. 